\title{
Effect of Organic Management Practices on Growth, Yield Attributes and Grain Yield in Mustard (Brassica juncea (L.) Czern. and Coss.)
}

\author{
Ashok Kumar*, Alok Kumar, Pushpendra Kumar, Yogesh, \\ L.K. Yadav and Rajesh Kumar \\ Department of Soil Science \& Agricultural Chemistry, Narendra Deva University of \\ Agriculture and Technology, Kumarganj, Faizabad-224229(U.P.), India \\ *Corresponding author:
}

A B S T R A C T

\begin{tabular}{|c|}
\hline Keywords \\
\hline $\begin{array}{l}\text { FYM, Organic } \\
\text { practices, Mustard, } \\
\text { Productivity, Soil } \\
\text { fertility, Economics }\end{array}$ \\
\hline Article Info \\
\hline $\begin{array}{l}\text { Accepted: } \\
\text { 24 July } 2018 \\
\text { Available Online: } \\
\text { 10 September } 2018\end{array}$ \\
\hline
\end{tabular}

\section{Introduction}

Indian mustard (Brassica juncea (L.) Czern. and coss.) belongs to the family Cruciferae. India is one of the largest mustard growing countries in the world, occupying the first position in area and third in production after China and Canada. It is most important winter (Rabi) oil seed crop in northern India. Among the seven edible oilseed crop cultivated in
The study was undertaken to evaluate the long-term effect of organic management practices against integrated use of nutrient sources and chemical fertilizer treatments on mustard productivity and soil fertility. The integrated use of nutrient sources viz., 50\% recommended doses of NPKS through chemical fertilizer and 50\% $\mathrm{N}$ through FYM provided highest seed yield, yield attributes and total uptake of $\mathrm{N}, \mathrm{P}, \mathrm{K}$ which was at par to the $100 \%$ chemical fertilizer (NPKS) treatment. The organic treatments received $100 \%$ recommended $\mathrm{N}$ combindly through $\mathrm{FYM}+$ neem cake + vermicompost ( $1 / 3$ from each source) along with different management practices provided lower yields. The reduction in dose of nutrients (50\% FYM along with bone meal, PSB and Azotobacter) provided significantly lower yield and nutrient (NPK) uptake. The regular application of $100 \%$ nutrients through organic sources (FYM $+\mathrm{VC}+\mathrm{NC}$ ) showed appreciable increase in organic carbon and availability of nutrients (NPK) and higher decline in soil pH and EC as compared to INM and fertilizer treatments. The availability of nutrients in $100 \%$ NPKS through chemical fertilizers and INM treatment was at par. The higher profit was obtained in INM treatment followed by $100 \%$ chemical fertilizer treatment. The conjunctive use of organic sources and fertilizer (INM) proved conducive in sustaining soil fertility and productivity of mustard in long run. 
2013). The excessive use of agrochemicals for the last 50 years though, helped in achieving commendable progress earlier, but the least attention to ecological agricultural principles resulted in deceleration of growth and stagnation in crop yield which cause serious concern and chain of several problems has been tackled in the recent decades. Indiscriminate use of chemical fertilizers and pesticides resulted several deleterious effects on soil, water and air causing their resultant pollution. This has reduced the productivity of the soil by deteriorating the soil health in terms of soil fertility and microbial activity. It improves physical, chemical and biological properties of soil with higher microbial biomass carbon and respiration activities. Despite many fold advantages of organic farming and organic foods, organic inputs do not respond immediately particularly in the soil with wide $\mathrm{C}$ : $\mathrm{N}$ ratio. It entails the use of compost, FYM, vermicompost, crop residues, green manures, green leaf manuring in crop rotation and biofertilizers to enrich the soil organic carbon, supply all essentially required plant nutrients and improve soil properties. Nutrient management through organics plays a major role in maintaining soil health due to buildup of soil organic matter, beneficial microbes and enzymes. Long-term addition of organic materials to soil resulted as an increase in organic matter, crop productivity and soil biological activity (Collins et al., 1992).

\section{Materials and Methods}

The experiment was conducted at agronomy research farm of N.D. university of Agriculture and Technology, Faizabad (U.P.), at $26^{0} 28 \mathrm{~N}$ latitude, $82^{0} 12 \mathrm{E}$ longitude and at an altitude of $113 \mathrm{~m}$ above the mean sea level. The experiment was conducted under randomized block design with 6 treatments and 4 replications during the year 2013-14. Soils of experimental field was silt loam in texture, low in organic carbon, available nitrogen and available sulphur, medium in available phosphorus, potassium and alkaline in reaction. The mustard variety, NDR-8501 was sown in $15^{\text {th }}$ nov, 2013 at the rate of $5 \mathrm{~kg}$ $\mathrm{ha}^{-1}$ after application of treatments wise manure and fertilizers with $60 \mathrm{~cm}$ row spacing to evaluate the observation regarding growth attributes and yield components. Three irrigations were applied during crop season at branching stage $30 \mathrm{DAS}$, flowering stage 50 DAS and pod filling stage 85 DAS. The crop was harvested on $20^{\text {th }}$ march 2014. Different aspects taken in the investigation were growth attributes e.g. plant height, primary branches plant $^{-1}$, Secondary branches plant ${ }^{-1}$, no. of siliqua plant ${ }^{-1}$, no. of seed siliqua ${ }^{-1}$ test weight (weight of 1000 seed in gm) respectively.

\section{Observation recorded}

\section{Plant height}

Five plants were selected randomly from each plot and tagged. The height was measured at the time of 30, 60, 90 days and at the harvest stage, in $\mathrm{cm}$ with the help of meter scale from the base of the plant to top of the plant and mean value was computed.

\section{Number of primary and secondary branches:}

Five selected tagged plants were also used for counting of primary and secondary branches at harvest. Total number of primary and secondary branches were counted separately and mean value have been computed for primary and secondary branches plant ${ }^{-1}$.

\section{Number of siliqua plant ${ }^{-1}$}

The siliqua of five randomly selected plants were separated and counted. The average value was reported as number of siliqua plant ${ }^{-}$ 1 . 


\section{Number of seed siliqua ${ }^{-1}$}

Twenty randomly selected siliqua taken from respective five plant, where threshed and seeds were counted. The average number of seed was reported as number of seed siliqua ${ }^{-1}$.

\section{Test weight}

Sample of seeds was drawn from the produce of each net plot and one thousand seeds were counted from each treatment. The counted seeds were weighed and recorded as test weight.

\section{Seed yield}

Each net plot was threshed separately. The weight of seeds was recorded and finally converted into quintal ha ${ }^{-1}$.

\section{Stover yield}

Stover yield was computed by deducting the seed yield from the total biological yield and converted into quintal ha ${ }^{-1}$.

\section{Results and Discussion}

This study included plant height, number of primary branches plant ${ }^{-1}$, number of secondary branches plant ${ }^{-1}$, siliqua plant $^{-1}$, seed siliqua ${ }^{-1}$ and test weight.

\section{Plant height}

The maximum plant height $(186 \mathrm{~cm})$ at harvest stage was recorded in INM treatment, received $50 \%$ recommended doses of NPKS through chemical fertilizer and 50\% $\mathrm{N}$ through FYM which was at par to the pure organic treatments received $100 \%$ recommended $\mathrm{N}$ through FYM + vermicompost + neem cake and fertilizer treatment received $100 \%$ NPKS through fertilizers alone. Arya et al. (2007) reported that integrated use of fertilizers with organic materials significantly enhanced average plant height and plant biomass in mustard. Similar findings were also observed by Nagdive et al. (2007) and Dongarwar et al. (2007) (Table 1).

\section{Number of primary branches}

The number of primary branches was found maximum in $\mathrm{T}_{1}(50 \% \mathrm{RDF}$ of NPKS $+50 \%$ FYM) over $\mathrm{T}_{5}(50 \% \quad \mathrm{FYM}+\mathrm{BM}+\mathrm{AZ}+\mathrm{PSB})$ which gave lower number of primary branches per plant. It was clearly indicated that integration of FYM as a organic source with $50 \%$ RDF of NPKS as inorganic source proved most significant in terms of increasing number of branches per plant. Branching is a major yield contributing character. The present study and the results thereof corroborated by findings of several workers. The results were most closely corroborated with Singh and Singh (2005) and Dongrawar et al. (2007).

\section{Number of Secondary branches}

It is clear from the data recorded that the effect of different organic management practices was significant on the number of secondary branches/plant and found more number of secondary branches per plant in $\mathrm{T}_{1}$ (50\% RDF of NPKS $+50 \%$ FYM) which was found similar to $\mathrm{T}_{6}(100 \% \mathrm{RDF}$ of NPKS) comparison to $\mathrm{T}_{5}(50 \% \mathrm{FYM}+\mathrm{BM}+\mathrm{AZ}+\mathrm{PSB})$ gave lower number of secondary branches per plant.

Application of $50 \%$ inorganic and $50 \%$ organic fertilizers after soil test value might have increased the availability of nitrogen being an essential constituent of nucleic acid, protoplasm and protein, plays a fundamental role in metabolism, growth, development and transmission of heritable characters therefore, no. of secondary branches also increased by this condition. These results were in 
conformity with those of Prasad and NPKS as a inorganic source and 50\% FYM as Ehsanullah (1988) and Nagdive et al., (2007).

\section{Number of siliqua plant ${ }^{-1}$}

The data showed in Table 2, the number siliqua plant $^{-1}$ was varied from 248.0 to 283.0 and lowest and highest value given by $\left(\mathrm{T}_{5}\right)$ : $50 \% \quad \mathrm{FYM}+\mathrm{BM}+\mathrm{AZ}+\mathrm{PSB}$ and $\left(\mathrm{T}_{1}\right): 50 \%$ NPKS+50\% FYM. Addition of $50 \%$ RDF of a organic sources responses well and gave significantly higher number of siliqua per plant comparison to other treatment combinations. The results are in agreement with those of Ramesh et al., (2009) who observed higher values of growth and yield attributes due to integrated application of fertilizers with FYM and biofertilizers.

Table.1 Effect of various organic management practices on growth and yield attributing characters

\begin{tabular}{|c|c|c|c|c|c|c|}
\hline Treatments combinations & $\begin{array}{l}\text { Plant height } \\
\text { (cm) }\end{array}$ & $\begin{array}{l}\text { No. of primary } \\
\text { branches }\end{array}$ & $\begin{array}{c}\text { No. of } \\
\text { secondary } \\
\text { branches }\end{array}$ & $\begin{array}{c}\text { No. of } \\
\text { siliqua/plant }\end{array}$ & $\begin{array}{c}\text { No. of } \\
\text { seed/siliqua }\end{array}$ & $\begin{array}{l}\text { Test weight } \\
\text { (gm) }\end{array}$ \\
\hline $\begin{array}{l}\mathrm{T}_{1}: \quad 50 \% \\
50 \% \text { FYM }\end{array}$ & 186 & 5.16 & 16 & 283 & 13.2 & 4.41 \\
\hline $\mathrm{T}_{2}: \mathrm{FYM}+\mathrm{VC}+\mathrm{NC}$ & 181 & 5.01 & 13 & 266 & 11.8 & 4.39 \\
\hline T3: T2 +HW + PP & 183 & 5.07 & 14 & 273 & 12.6 & 4.40 \\
\hline$T_{4}: T_{2}+A Z+P S B$ & 180 & 5.04 & 14 & 271 & 12.3 & 4.42 \\
\hline $\begin{array}{l}\mathrm{T}_{5}: 50 \% \mathrm{FYM}+\mathrm{BM}+\mathrm{AZ}+ \\
\text { PSB }\end{array}$ & 174 & 4.80 & 11 & 248 & 11.2 & 4.38 \\
\hline$T_{6}: 100 \%$ NPKS & 184 & 5.10 & 16 & 277 & 12.9 & 4.40 \\
\hline CD (5\%) & 3.09 & 0.06 & 0.51 & 6.28 & 0.32 & 0.015 \\
\hline $\operatorname{Sem}( \pm)$ & 9.0 & 0.18 & 1.5 & 18.3 & 0.96 & NS \\
\hline
\end{tabular}

Table.2 Effect of various organic management practices on growth and yield attributing characters

\begin{tabular}{|c|c|c|c|}
\hline Treatment combinations & $\begin{array}{l}\text { Grain yield } \\
\text { (q/ha) }\end{array}$ & $\begin{array}{l}\text { Stover yield } \\
\text { (q/ha) }\end{array}$ & $\begin{array}{l}\text { Harvest Index } \\
\text { (H.I.) }\end{array}$ \\
\hline $\mathrm{T}_{1}: 50 \%$ NPKS 50\%FYM & 18.6 & 52.1 & 26.30 \\
\hline $\mathrm{T}_{2}: \mathrm{FYM}+\mathrm{VC}+\mathrm{NC}$ & 15.6 & 43.5 & 26.39 \\
\hline$T_{3}: T_{2}+H W+P P$ & 16.8 & 46.5 & 26.54 \\
\hline $\mathrm{T}_{4}: \mathrm{T}_{2}+\mathrm{AZ}+\mathrm{PSB}$ & 16.4 & 44.9 & 26.75 \\
\hline $\mathrm{T}_{5}: \mathbf{5 0 \%} \mathrm{FYM}+\mathrm{BM}+\mathrm{AZ}+\mathrm{PSB}$ & 13.7 & 38.7 & 26.14 \\
\hline$T_{6}: 100 \%$ NPKS & 17.3 & 48.3 & 26.37 \\
\hline SEm \pm & 0.64 & 1.86 & - \\
\hline $\mathrm{CD}(\mathrm{P}=\mathbf{0 . 0 5})$ & 1.9 & 5.4 & - \\
\hline
\end{tabular}

RDF=Recommended Dose of Fertilizer, $\mathrm{PSB}=$ Phosphorus Solubilizing Bacteria, $\mathrm{BM}=$ Bone Meal, FYM= Farm Yard Manure, $\mathrm{AZ}=$ Azotobacter, $\mathrm{VC}=$ Vermicompost, $\mathrm{NC}=$ Neem Cake, $\mathrm{PP}=$ Plant Protection, $\mathrm{HW}=$ Hand Weeding, RDF of NPKS was applied @ of 120:60:40:4 


\section{Number of seeds Siliqua ${ }^{-1}$}

As data depicted in Table 2 the number of seeds siliqua ${ }^{-1}$ ranges from 11.2 to 13.2 and lowest and highest value given by $\left(\mathrm{T}_{5}\right)$ ): $50 \%$ $\mathrm{FYM}+\mathrm{BM}+\mathrm{AZ}+\mathrm{PSB}$ and $\left(\mathrm{T}_{1}\right): 50 \%$ NPKS $+50 \%$ FYM. $T_{1}$ gave the highest value which was significantly superior over $T_{5}$ treatment. It was clear that integrated application of FYM @ 8.0 tonne ha ${ }^{-1}$ with $50 \%$ doses of RDF of NPKS gave significant response comparison to sole organic or inorganic source. A number of investigators have observed increases in these attributes in mustard crop viz., Tripathi et al (2010), Chaurasiya et al., (2009), Ramesh et al. (2009) and Kashved et al., (2010). The results of present study are in agreement with the findings of above workers.

\section{Thousand grain- test weight}

The data pertaining to 1000 seed weight (test weight) have been given in Table 2 Results revealed that variations in 1000 seed weight of different treatments were non-significant. However, the maximum test weight $(4.42 \mathrm{~g})$ was recorded in treatment $\mathrm{T}_{4}(100 \%$ nutrients through organics + PSB + Azotobacter) closely followed by INM treatment- $\mathrm{T}_{1}(50 \%$ $\mathrm{NPKS}+50 \% \mathrm{~N}$ through FYM) and $100 \%$ fertilizer treatment $\left(\mathrm{T}_{6}\right)$. The lowest test weight $(4.38 \mathrm{~g})$ was recorded in treatment $\mathrm{T}_{5}$ having only $50 \% \mathrm{~N}$ through FYM with bone meal ( $\mathrm{P}$ source) and seed treatment with Azotobacter + PSB. Similar results have been reported by Kasved et al. (2010) and Tripathi et al. (2010).

\section{Grain and stover yield}

The grain yield varied from 13.7 to $18.6 \mathrm{q} \mathrm{ha}^{-1}$ whereas stover yield ranges from 38.7 to 52.1 $\mathrm{q} \mathrm{ha}^{-1}$ in our present investigation. Integration of organic source (FYM) with inorganic sources (RDF of NPKS) gave significantly higher yield in terms of grain and stover. The application of sulphur with FYM and inorganic nutrients increases the size of grain and vigourness of grain due to its pivotal role in oil synthesis in all oilseed crops. Treatment $\mathrm{T}_{1}$ : (50\% RDF of NPKS $+50 \%$ FYM) which gave highest grain $\left(18.6 \mathrm{qha}^{-1}\right)$ and stover $\left(52.1 \mathrm{qha}^{-1}\right)$ yield comparison to the yield of $\mathrm{T}_{5}$ : (50\% FYM+BM+AZ+PSB) $13.7 \mathrm{qha}^{-1}$, $38.70 \mathrm{qha}^{-1}$. Our results are corroborated with Laxminarayan et al., (2006) and Aulakh et al., (2010).

\section{Harvest index}

The data of harvest index, presented in Table 2 did not show any significant differences among the various treatments. However, the highest value (26.75) was obtained in the treatment received $100 \% \mathrm{~N}$ through organic sources (FYM + VC + NC) alone with seed treatment of PSB + Azotobacter $\left(\mathrm{T}_{4}\right)$ closely followed by treatment $\mathrm{T}_{3^{-}}$having management practices (hand weeding and plant protection) along with $100 \% \mathrm{~N}$ through organic manures and $\mathrm{T}_{6^{-}} 100 \%$ nutrients (NPKS) through chemical fertilizers. The minimum value of harvest index (26.14) was obtained in treatment $\mathrm{T}_{5}$ - received only $50 \%$ $\mathrm{N}$ through FYM with bone meal, PSB and Azotobacter. Present investigation is in close conformity with the findings of Abraham et al. (2008) and Maheshbabu et al. (2008).

In conclusion, integrated use of nutrients regularly viz., $50 \%$ recommended dose of NPKS through chemical fertilizers and 50\% $\mathrm{N}$ equivalent farm yard manure provided higher yield of mustard which was comparable to $100 \%$ recommended NPKS through chemical fertilizers alone. Integrated use of nutrients regularly viz., $50 \%$ recommended dose of NPKS through chemical fertilizers and $50 \% \mathrm{~N}$ equivalent farm yard manure provided higher yield of mustard which was comparable to $100 \%$ 
recommended NPKS through chemical fertilizers alone.

\section{References}

Abraham, T., Thenua, O.V. S., Singh, S.P. and Jacob, P. 2008. Performance of groundnut as influenced by organic and inorganics sources of nutrients and their method of application. Legume Res. 31: 224-226.

Anonymous (2013). Economic survey of India. Economic Division, Ministry of Finance, Govt. of India, New Delhi.

Aulakh, M. S. (2010). Integrated nutrient management for sustainable crop production, improving crop quality and soil health, and minimizing environmental pollution. Proceedings of the 19th World Congress of Soil Science: Soil solutions for a changing world, Brisbane, Australia, 1-6 August 2010. Symposium 4.1.2 Management and protection of receiving environments, 79-82.

Collins, H.P.; Rasmussen, P.E. and Douglas, C.L. (1992). Crop rotation residue management effect of soil carbon and microbial biomass dynamics. Soil.Soc. Am. J., 56: 783-788.

Chaurasiya, Anand, Singh A.B. and Namdev, K.N. 2009. Integrated nutrient management in relation to yield and yield attributes and oil Yield of Ethopian mustard (Brassica carinata). Crop Res. (Hissar). 38 (1/3): 24-28.

Dongarwar, U. R.; Bhalerao, P.D. andNegduie, S. J. (2007). Effect of irrigation and INM on growth and yield of Indian mustard.
Annals Physiol., 21(2): 182-185.

Kashved, S. M., Raskar, B. S. and Tamboli, B. D. (2010). Effect of integrated nitrogen management and irrigation regimes on productivity mustard (Brassica juncea L.). Journal of Maharashtra Agricultural Universities, 35(3): 349-353.

Laxminarayana, K. and Patiram (2006). Effect of integrated use of inorganic, biological and organic manure on rice productivity and soil fertility in Ultisols of Mizoram. $J$. Indian Soc. Soil Sci., 45 (20): 213-220.

Maheshbabu, H.M., Ravi Hunjem, Patil, N.K. B. and Babalad, H.B. 2008. Effect of organic manures on plant growth, seed yield and quality of soybean. Karnataka. J. Agric. Sci. 21:219-221.

Nagdive, S. J.; Bhalerao, P. D. and Dongarwar, U. R. (2007). Effect of irrigation and integrated nutrient management on growth and yield of Indian mustard. Annals of Plant Physiology, 21(2): 182-185.

Prasad, U.K. and Ehsanullah, M. 1988. Effect of irrigation and nitrogen on yield and yield attributes of mustard. Indian $J$. Agron., 33(1):47-51.

Ramesh, P.; Panwar, N. R.; Singh, A. B. and Ramana, S. (2009b.). Effect of organic nutrient management practices on the production potential, nutrient uptake, soil quality, input-use efficiency and economics of mustard (Brassica juncea). Indian J. Agric. Sci., 79 (1):40-44.

Singh H, Choudhary R, Lal M. 2005. Effect of nitrogen, sulphur and Azotobacter on growth yield and uptake of nutrients by mustard. Ann. Pl. Soil Res., 7:72- 74.

\section{How to cite this article:}

Ashok Kumar, Alok Kumar, Pushpendra Kumar, Yogesh, L.K. Yadav and Rajesh Kumar. 2018. Effect of Organic Management Practices on Growth, Yield Attributes and Grain Yield in Mustard (Brassica juncea (L.) Czern. and Coss.). Int.J.Curr.Microbiol.App.Sci. 7(09): 35853590. doi: https://doi.org/10.20546/ijcmas.2018.709.444 